\title{
ARTYKUŁY
}

\section{ZDROWOROZSĄDKOWE A FILOZOFICZNE POZNANIE ATRYBUTÓW BOGA}

\begin{abstract}
Streszczenie. Problem rozważany w tym artykule dotyczy relacji między zdroworozsądkowym a filozoficznym (realistycznym) poznaniem atrybutów Boga. Na przykładzie wszechmocy, wszechwiedzy i wszechobecności Boga dochodzi się do wniosku, że w oparciu o bezpośrednio daną rzeczywistość i przy zastosowaniu tylko poznania zdroworozsądkowego człowiek nie doświadcza tego rodzaju własności w świecie, lecz przypisuje je Bogu. Natomiast sam z siebie nie potrafi ich uzasadnić. Kwestią uzasadnienia problemów, powstających na gruncie poznania potocznego, zajmuje się m.in. filozofia. Dlatego przyjmuje się, że filozofia koryguje i uzupełnia poznanie przednaukowe. Jednakże dla samego orientowania się i uznania wspomnianych przymiotów Boga poznanie zdroworozsądkowe jest wystarczające.
\end{abstract}

Słowa kluczowe: poznanie; zdrowy rozsądek; filozofia; atrybuty Boga; wszechmoc; wszechwiedza; wszechobecność; antynomia

1. Wstęp. 2. Zdroworozsądkowy typ poznania. 3. Wszechmoc. 4. Wszechwiedza. 5. Wszechobecność. 6. Podsumowanie.

\section{WSTĘP}

Zdaniem św. Tomasza z Akwinu poznanie istnienia Boga i niektórych Jego atrybutów (Wojtysiak 2013)1 dokonuje się na trzy sposoby. Pierwszym z nich jest poznanie naturalne (filozoficzne), które rozpoczyna się od rzeczy stworzonych. Drugi sposób wiąże się z przyjęciem objawienia religijnego (wiara), czyli tego, co Bóg mówi o sobie. Trzecim sposobem jest poznanie mistyczne (Tomasz z Akwinu 2003).

1 W opracowaniach na ten temat zamiennie używa się określeń: przymioty, doskonałości, atrybuty, istota, natura, własności, właściwości Boga. Ponadto są one ze sobą powiązane w taki sposób, że jedne atrybuty wynikają z innych i są od siebie zależne. 
Oprócz tego literatura przedmiotu podaje jeszcze inne sposoby, prowadzące do poznania Boga i jego przymiotów. Jednym $z$ nich jest poznanie afektywne, a innym - społeczny przekaz wiary (Moskal 2008) ${ }^{2}$. Znamienne, że wśród wskazanych metod poznania Boga i jego podstawowych własności sporadycznie lub wcale nie występuje poznanie zdroworozsądkowe. A przecież tylko niektórzy są filozofami, nie wszyscy mają wiarę, za to każdy człowiek poznaje dzięki zdrowemu rozsądkowi (Sieńkowski 2014).

Celem poniższych analiz jest zestawienie dwóch sposobów poznania atrybutów Boga, czyli zdroworozsądkowego i filozoficznego, przy czym oba rodzaje poznania są tu rozumiane $\mathrm{w}$ duchu realistycznym (arystotelesowsko-tomistycznym) (Leszczyński 2011)3. Konfrontacja tego typu zmierza do ustalenia, czy poznanie zdroworozsądkowe wystarcza do poznania własności Boga, czy też domaga się wsparcia ze strony filozofii. Jeśli zachodzi drugi przypadek, to będzie on potwierdzeniem zasady, zgodnie z którą poznanie filozoficzne koryguje i uzupełnia poznanie potoczne. Ponieważ analiza wszystkich lub nawet wielu przymiotów Boga jest zadaniem przekraczającym ramy artykułu, zostaną omówione tylko wybrane atrybuty: wszechmoc, wszechwiedza i wszechobecność (Jaworski 1969)4. Jednak najpierw zostanie przybliżone rozumienie poznania zdroworozsądkowego.

2 Religię (objawienie), osobiste doświadczenie religijne i filozofię jako źródła poznania atrybutów Boga wymienia Dariusz Łukasiewicz (Łukasiewicz 2016).

3 Należy zauważyć, że podobnie jak nie sposób mówić o jednej filozofii, tak też trzeba wskazać różne typy zdrowego rozsądku. Koncepcja zdrowego rozsądku, zapoczątkowana przez T. Reida, różni się od realistycznego ujęcia poznania zdroworozsądkowego, zaproponowanego przez Arystotelesa. Jeszcze innym rozumieniem zdrowego rozsądku posługuje się Kartezjusz.

4 Chodzi tu o koncepcję Boga, rozumianą w duchu filozofii realistycznej i utożsamianą z pojęciem Boga religii chrześcijańskiej. 


\section{ZDROWOROZSĄDKOWY TYP POZNANIA}

Na zdrowy rozsądek można spoglądać zarówno od strony przedmiotowej, jak i podmiotowej. Z przedmiotowego punktu widzenia jest on przede wszystkim zbiorem prostych i podstawowych przekonań, podzielanych przez większość ludzi (Gilson 1968). Natomiast $\mathrm{w}$ aspekcie podmiotowym zdrowy rozsądek określa się jako dyspozycję poznawczą, dzięki której ujmuje się rzeczywistość w jej najbardziej podstawowych aspektach (Daszkiewicz 2008). Ten typ poznania zwie się przednaukowym, przedfilozoficznym, potocznym, spontanicznym, lecz nie naiwnym, chaotycznym czy irracjonalnym (Krąpiec 1993; Kamiński 1989; Stępień 1989; Tatarkiewicz 1986).

Zdaniem Arystotelesa zdrowy rozsądek obejmuje powszechnie uznane przekonania, które służą za podstawę dowodzenia (Arystoteles 2009). Same jednak nie podlegają dowodzeniu, gdyż przyjmuje się je na zasadzie oczywistości. Przekonania te są znane w sposób naturalny, bezpośredni i spontaniczny. Rodzą się w wyniku bezpośredniego (zmysłowego-intelektualnego) doświadczenia świata lub dzięki prostym aktom umysłowym. W związku z tym przyjmują postać sądów, a swoją podstawę mają w realnie istniejącej rzeczywistości (Tomasz z Akwinu 1961-1986)5.

Warto dodać, że odpowiednikami przekonań zdrowego rozsądku na gruncie filozofii są tzw. pierwsze zasady (Maryniarczyk 2001; Herbut 2000; Mazur 2004). W języku potocznym mogą one przybierać następujące brzmienie: żadna rzecz nie jest drugą rzeczą; nie można jednocześnie być i nie być (mieć i nie mieć); każdy skutek ma swoją przyczynę (nic się nie dzieje bez przyczyny); każde działanie jest celowe. Z kolei na gruncie filozofii ich treść oznacza, że: byt jest bytem; byt nie jest podzielony na byt i nie-byt; między jednym

5 Zasady zdrowego rozsąadku posiadają następujące własności: (1) są oczywiste; (2) zaprzeczanie im prowadzi do absurdu; (3) myślenie, zmierzające do obalenia zasad, opiera się na nich; (4) stanowią podstawę praktycznych działań człowieka (Daszkiewicz 2008). 
a drugim bytem nie ma nic pośredniego; każdy byt ma swoją rację; wszystko działa dla celu. Zarówno w potocznym, jak i w filozoficznym ujęciu zasady te decydują o sposobie istnienia i poznania rzeczy (Tomasz z Akwinu 1961-1986) ${ }^{6}$. Nie należy jednak zapominać, że oprócz wymienionych wyżej zasad na zdrowy rozsądek składają się także inne różnego rodzaju przekonania, teorie, opinie, uprzedzenia, a nawet wierzenia ${ }^{7}$. Uściśleniem tego rodzaju danych zajmuje się poznanie wyższego rzędu w postaci filozofii czy nauki.

W opracowaniach poświęconych zdrowemu rozsądkowi podkreśla się, że jego zasady funkcjonują na trzech poziomach. Pierwszym $z$ nich jest sfera intuicji zmysłowej. Dotyczy ona rzeczy realnie istniejących w świecie i obejmuje oczywistości z nimi związane. Drugi to porządek intuicji intelektualnej. Obejmuje on relacje między istnieniem a poznaniem rzeczy. W trzecim obszarze chodzi o konsekwencje, wynikające $z$ dwóch pierwszych poziomów, czyli o podstawowe zasady światopoglądowe, obyczajowe i moralne (Krąpiec 1995).

Do tego ostatniego zalicza się zdroworozsądkowe przekonanie o istnieniu Boga ${ }^{8}$. Jednak należy pamiętać, że jest to sąd przednau-

6 Inne przykładowe przekonania zdroworozsądkowe to: całość jest większa od części; jeden przedmiot znajduje się w jednym miejscu; dobro należy czynić (Krąpiec 2008; Daszkiewicz 2014).

7 Być może należy odróżniać poznanie zdroworozsądkowe od poznania potocznego, jednakże nie czyni się tego w tym opracowaniu. Jeśli to ostanie pozostaje pod wpływem czynników pozapoznawczych (np. mitologii), to poznanie zdroworozsądkowe zmierza do ich wyeliminowania. W związku z tym filozofia realistyczna bazuje na zdrowym rozsądku, a nie na poznaniu potocznym.

8 W celu potwierdzenia tego, że przekonanie o istnieniu Boga nie pojawia się tylko na gruncie religii lub filozofii, warto przytoczyć dłuższą wypowiedź M.A. Krąpca: „Człowiek bowiem, zanim dojdzie (w wyniku przeprowadzonego metodycznie myślenia co do istnienia Boga i duszy) do pozytywnego czy negatywnego przekonania, wpierw uświadamia sobie, iż rodzi się w nim jakieś, może nawet mgliste, przeświadczenie o istnieniu lub co najmniej o rzeczywistej możliwości istnienia Boga i własnej duszy. Sprawy te na razie tylko dostrzega swoim rozumem, lecz nie posiada jeszcze uzasadnienia, w wyniku czego powstaje pewien duchowy niepokój, domagający się wytłumaczenia takich właśnie percepcji poznawczych" (Krąpiec 1995, 47). W podobnym duchu wypowiada się J. Maritain (Maritain 1946-1947, 
kowy. Zdrowy rozsądek jest w stanie dojść do wniosku, że Bóg istnieje, lecz nie przez doświadczenie, a w drodze rozumowania, które ma charakter poznania pośredniego (Tupikowski 2008; Kamiński 2017; Daszkiewicz 2007). Podobnie jak jednym z przekonań zdroworozsądkowych jest to, które głosi, że każda rzecz ma swoją przyczynę, tak również świat jako całość jest uprzyczynowany. Tego rodzaju wniosek człowiek wysuwa już w poznaniu zdroworozsądkowym, a nie tylko w filozoficznym czy religijnym. Przy czym jest to wniosek, który na tym etapie poznania nie posiada jeszcze pełnego uzasadnienia9.

Zdrowy rozsądek odnosi się przede wszystkim do realnie istniejącego świata. Jego przedmiotem jest rzeczywistość dana w bezpośrednim doświadczeniu. Stanowi ją to, z czym człowiek ma bezpośredni kontakt. Dlatego podkreśla się, że poznaje on przede wszystkim rzeczy oraz osoby, w tym także siebie samego. Bezpośrednie doświadczenie rzeczywistości sprawia, że zdrowy rozsądek w sposób przednaukowy poznaje prawa i zasady, które rządzą istnieniem rzeczy i osób. Ponadto podejmuje się zrozumienia zachodzących w świecie podstawowych zjawisk. Dokonuje się to m.in. przez poszukiwanie i wskazanie ich przyczyn i zależności. W ten sposób już na poziomie poznania potocznego dochodzi się do stwierdzenia istnienia Boga - przyczyny wszystkich rzeczy. Oczywiście jest to poznanie nie posiadające jeszcze naukowego uzasadnienia, które pojawi się w wyniku dalszego i głębszego dociekania. Oprócz tego w poznaniu potocznym dochodzi również do sformułowania podstawowych własności Boga ${ }^{10}$.

Krąpiec 1981). Z kolei E. Gilson twierdzi, że idea (przed-wiedza) Boga jest człowiekowi wrodzona (Gilson 1996).

9 Takie rozumienie kwestii istnienia Boga jest przyjmowane na gruncie poznania realistycznego, czy to zdroworozsądkowego, czy filozoficznego (Tomasz z Akwinu 1998; Krąpiec 1995; Zdybicka 1977; Moskal 2000; 2008; Tarasiewicz 2011; Sieńkowski 2020).

10 Np. dobroć, mądrość, wszechmoc, nieskończoność itp. (Kowalczyk 2009). 
Zdrowy rozsądek nie ogranicza się tylko do stwierdzenia istnienia Boga, lecz podejmuje się również określenia jego atrybutów. Trudno oczekiwać, aby czynił to w sposób ostateczny i bezdyskusyjny, jednakże nie jest bez znaczenia, że tego typu wysiłek dostarcza pewnej wiedzy na temat natury Boga (Kamiński 1998). Aby przekonać się, jaka relacja zachodzi między zdroworozsądkową a filozoficzną wiedzą w zakresie natury Boga, poniżej zostaną omówione niektóre jego atrybuty i związane $z$ nimi problemy ${ }^{11}$.

\section{WSZECHMOC}

Raczej nikogo nie powinno dziwić to, że na gruncie zdrowego rozsądku pojęcie wszechmocy jest rozumiane dosłownie, czyli jako moc uczynienia wszystkiego bez wyjątku. Natomiast nie bez znaczenia pozostaje to, w jaki sposób zdrowy rozsądek dochodzi do takiego rozumienia wszechmocy. Aby wyjaśnić tę kwestię, wpierw należy zastanowić się nad relacją wszechmocy do tych rodzajów bytów, które są bezpośrednio dane człowiekowi. Dlatego w pierwszej kolejności należy pytać o moc rzeczy oraz człowieka.

$\mathrm{Na}$ podstawie doświadczenia świata, na który składają się byty przygodne, zdrowy rozsądek dochodzi do przekonania, że żaden $\mathrm{z}$ nich nie dysponuje wszechmocą w dosłownym rozumieniu. Ponieważ byty tego rodzaju powstają i giną oraz posiadają, powiększają lub uzupełniają braki, nie są w stanie działać inaczej, niż pozwala im na to ich własna natura (Krąpiec 1995). Natura bytów przygodnych jest ograniczona różnymi uwarunkowaniami, które decydują o tym, że nie jest możliwe uczynienie wszystkiego. Sprawiają one tylko to, co jest w zasięgu ich możliwości. W związku z tym w bezpośrednio

11 Na temat relacji między zdrowym rozsądkiem a filozofią zob. Krąpiec 1995. Celem tego artykułu nie jest to, aby owe problemy ukazać w pełnym kształcie z uwzględnieniem współczesnych rozwiązań i najnowszej literatury. Chodzi raczej o to, aby się przekonać, czy poznanie potoczne radzi sobie z ich rozwiązaniem, czy też potrzebuje dopełnienia w postaci poznania wyższego rzędu. 
dostępnym świecie człowiek nie napotyka żadnego bytu działającego (sprawcy), który dysponowałby nieskończoną mocą.

Poznając inne osoby oraz siebie samego, człowiek doświadcza różnego rodzaju działań sprawczych i ich skutków. W wyniku tego poznania dostrzega również ograniczenia, a przez to stwierdza, że wszechmoc nie jest atrybutem człowieka. $Z$ reguły człowiek stale sięga po różnego rodzaju dobra, gdyż jako byt spotencjalizowany potrzebuje innym bytów-dóbr, które umożliwiają jego rozwój (Krąpiec 2005). Świadczy to o tym, że człowiek nie jest tak samowystarczalny ani doskonały, aby mógł obyć się bez innych dóbr. Już samo to przemawia za tym, że nie jest wszechmocny. Zgodne ze zdrowym rozsądkiem jest przekonanie, że nie wszystko może być uczynione przez człowieka ani przez inne byty działające. Ponieważ człowiek nie jest w stanie wywołać każdego stanu rzeczy, nie posiada atrybutu wszechmocy.

Odrębną kwestię stanowi wszechmoc przypisywana Bogu. Zostało już powiedziane, że za pomocą zdrowego rozsądku możliwe jest poznanie nie tylko tego, że Bóg istnieje, ale również niektórych jego przymiotów. Nic nie stoi na przeszkodzie, aby na poziomie poznania potocznego człowiek uznał, że Bóg jest wszechmocny. To rozumienie jest oczywiście przednaukowe, ale istotne jest to, że się w ogóle pojawia. Znaczy to, że zdrowy rozsądek już jakoś ujmuje to, co może być również przedmiotem badania na wyższym poziomie poznania ${ }^{12}$.

Jedynym rodzajem istnienia, któremu zdrowy rozsądek przypisuje wszechmoc, jest Bóg. W związku z tym uznaje się, że jest on

12 Jeśli pojęcia zdrowego rozsądku powstają w bezpośrednim kontakcie ze światem, to należy zauważyć, że pierwotne jest dostrzeżenie skończoności, braku, niewystarczalności. Wszechmoc powstaje na zasadzie zaprzeczenia przygodności i może się odnosić tylko do Boga na zasadzie wnioskowania, poszukiwania przyczyny wraz z jej własnościami. Posługując się kartezjańskim rozróżnieniem rodzajów idei, można powiedzieć, że wszechmoc jest pojęciem skonstruowanym, a nie nabytym lub wrodzonym (Tatarkiewicz 2002; Bejze 1968). 
zdolny spowodować zachodzenie każdego stanu rzeczy. Stworzony przez niego świat dowodzi, że przynależy mu taka moc, której nie posiada żaden inny byt, znany człowiekowi. Różnorodność bytów, ich złożoność, wielość relacji i dostrzegalna harmonia sprawiają, że zdrowy rozsądek pojmuje Boga jako wszechmocnego. Niewątpliwie ten sposób rozumienia wszechmocy Boga nie posiada pełnego uzasadnienia, ale jest już zarysowany.

Potoczne rozumienie wszechmocy nie jest tym samym, co refleksja filozoficzna. Wobec tego należy zapytać, jaki jest stosunek zdroworozsądkowego do filozoficznego poznania wszechmocy? Aby wskazać różnicę miedzy nimi, wystarczy poruszyć jedną z wielu trudności, którą jest chociażby problem antynomii (paradoksu) wszechmocy Boga ${ }^{13}$.

Z tym problemem nie radzi sobie poznanie przednaukowe. Chcąc go zilustrować, wystarczy postawić przytaczane często pytanie, czy Bóg może stworzyć taki przedmiot, którego sam nie udźwignie (przedmiot, którego nie może kontrolować) ${ }^{14}$. Skoro jest wszechmocny, to stworzy taki przedmiot. Ale z drugiej strony własnością tego przedmiotu jest to, z czym nie poradzi sobie nawet wszechmocny Bóg. W konsekwencji trzeba stwierdzić, że wszechmoc mu nie przysługuje. Powstający w ten sposób problem zwie się antynomią. Najprościej mówiąc, antynomia to dowód dwóch zdań sprzecznych na gruncie jakiegoś systemu. W tym wypadku są to zdania: „Bóg jest wszechmocny” oraz „Bóg nie jest wszechmocny” (Bremer 2008).

Antynomia tego typu powstaje w dwóch etapach. Najpierw przyjmuje się dosłowne rozumienie wszechmocy, zgodnie z którym Bóg może uczynić wszystko. Potem zaś konstruuje się taki stan rzeczy, którego wykonanie nie jest możliwe również dla wszechmocnego Boga. Za oczywiste uchodzi to, że nie można uczynić czegoś, co

13 Inne problemy związane z pojęciem wszechmocy omawia Stanisław Judycki (Judycki 2009; 2010).

14 W przystępny sposób antynomię tego rodzaju omawia Marcin Tkaczyk (Tkaczyk 2017). 
posiada sprzeczną naturę. Należy zauważyć, że stan rzeczy, skonstruowany $\mathrm{w}$ drugim etapie antynomii, zawiera $\mathrm{w}$ sobie absurd. Sprzecznością skutkuje posiadanie nad nim mocy. Innymi słowy najpierw Bóg posiada nieograniczoną moc, a następnie traci ją wobec absurdalnego stanu rzeczy (Tkaczyk 2017).

Trzeba uznać, że zdrowy rozsądek nie jest w stanie rozwiązać tego rodzaju antynomii. Poza jego zasięgiem leży zdolność zdemaskowania trudności i udzielenia uzasadnionej odpowiedzi na powstały problem. Natomiast radzi z nim sobie poznanie filozoficzne. Za M. Tkaczykiem próbę rozwikłania antynomii wszechmocy Boga na gruncie filozofii można rozpocząć od rozstrzygnięcia tego, czy dla każdej własności, którą potrafimy sformułować, istnieje zbiór przedmiotów, posiadających tę własność. Np. własność „bycie zielonym” posiada zbiór istniejących przedmiotów zielonych. Ale czy własności typu „bycie kwadratowym kołem” odpowiada zbiór istniejących kwadratowych kół? W tym wypadku odpowiedź jest negatywna, gdyż realnie nie istnieją koła o takiej własności. Stąd też potoczne rozumienie wszechmocy jako zdolności spowodowania każdego stanu rzeczy domaga się skorygowania na gruncie innego typu poznania. W związku z powstającą antynomią wszechmoc musi być rozumiana w sposób inny niż tylko dosłowny. Należy zdać sobie sprawę z tego, czy stan rzeczy, którego stworzenia domagamy się od wszechmocnego Boga, może istnieć realnie. Skonstruowanie (wymyślenie) dowolnej rzeczy, nawet sprzecznej w sobie, a następnie żądanie jej utworzenia, nie jest sprawdzianem na posiadanie wszechmocy. Sprzeczność nie może istnieć realnie (Tkaczyk 2017).

Analiza antynomii wszechmocy Boga potwierdza to, że myślenie (nawet o rzeczach sprzecznych) nie jest tym samym, co istnienie rzeczy w realnym świecie. Nie ma przejścia od myśli do rzeczywistości. Wprawdzie konstrukty myślowe mogą być dowolne, ale realne istnienie musi uwzględniać prawa rządzące rzeczywistością, w tym prawo niesprzeczności. Oczekiwanie od Boga stworzenia każdego stanu rzeczy jest lekceważeniem praw realnego istnienia w świecie 
(które zresztą on sam mu nadał), a w konsekwencji popadaniem w absurd i powątpiewaniem we wszechmoc Boga (Tkaczyk 2017).

W celu poprawnego rozumienia wszechmocy Boga nie można poprzestać tylko na poznaniu potocznym. Wbrew pierwotnej intuicji i zdrowemu rozsądkowi nie jest to zdolność wykonania wszystkiego. Dzięki poznaniu filozoficznemu pojęcie wszechmocy zyskuje poprawne rozumienie. Na gruncie filozofii wszechmoc to moc nadrzędna (władza) wobec istniejącej rzeczywistości (Reale 1999). Przejawia się ona m.in. w tym, że Bóg jako stwórca świata posiada moc do jego stworzenia, a jako sędzia ma moc do wymierzenia ostatecznej sprawiedliwości. W chrześcijaństwie (wyznania katolickiego) wszechmoc jest rozumiana jako absolutne panowanie Boga nad całym stworzeniem (Ratzinger 1994; 2020; Tkaczyk 2017). Nawet jeśli Bóg ma wszystko w mocy, nad wszystkim panuje, wszystkim włada, to nie oznacza, że może uczynić wszystko bez żadnych ograniczeń ${ }^{15}$.

\section{WSZECHWIEDZA}

W przypisaniu komuś wszechwiedzy (podobnie jak w przypadku problemu wszechmocy) pomocne jest zwrócenie uwagi na wiedzę różnego rodzaju bytów, bezpośrednio dostępnych człowiekowi. Potoczne rozumienie pojęcia wszechwiedzy oznacza, że ten, kto ją posiada, wie wszystko.

15 W taki sposób wszechmoc Boga pojmuje m.in. św. Augustyn (Augustyn 1952). Nawet jeśli Bóg może ustanowić każdy stan rzeczy, to nie znaczy, że jego wszechmoc jest nieograniczona. Należy pamiętać, że ograniczeniem wszechmocy Boga jest jego natura. Może on uczynić cokolwiek, o ile nie jest to niezgodne z jego naturą, a pośrednio z naturą stworzonego przez niego świata. Można powiedzieć, że Bóg napotyka na wewnętrzne ograniczenia, natomiast z zewnątrz nic nie stanowi dla niego przeszkody w działaniu. Wobec wewnętrznych ograniczeń pewne działania pozostają poza zasięgiem wszechmocy Boga. Np. Bóg nie może: stworzyć rzeczy zawierającej sprzeczność; skłamać lub zgrzeszyć; złamać obietnicy; zmienić przeszłości; unicestwić siebie, stworzyć Boga równego sobie (Tomasz z Akwinu 1961-1986; 2003; Arystoteles 2012; Koszkało, Pepliński 2016; Pepliński 2015; Tkaczyk 2017). 
Pomijając dyskusje na temat tego, kto jest podmiotem wiedzy, należy stwierdzić, że w ujęciu przednaukowym wiedzieć coś może tylko człowiek (osoba). Przy czym żaden człowiek nie wie wszystkiego. Wiedza jest przez niego stale nabywana, co oznacza, że był lub jest taki czas, gdy czegoś nie wiedział lub nie wie. Oprócz tego możliwa jest utrata wiedzy, czyli jej zapomnienie. Na podstawie tego rodzaju doświadczeń człowiek zdaje sobie sprawę, że nie jest wszechwiedzący.

W oparciu o poznanie potoczne zdrowy rozsądek żywi przekonanie, że wiedzieć wszystko (na temat dowolnego stanu rzeczy) może tylko i wyłącznie Bóg. Jego wiedza dotyczy zarówno wszystkich dziedzin, jak również czasu i sposobu jej zdobywania. Wprawdzie zdrowy rozsądek nie dokonuje naukowego uzasadnienia pojęcia wszechwiedzy Boga, jednakże na tym poziomie poznania istotne jest to, że atrybut wszechwiedzy przypisuje Bogu.

Jeden z problemów, którego rozwiązanie jest możliwe tylko na gruncie poznania wyższego rzędu niż poznanie potoczne, dotyczy tego, w jaki sposób można wiedzieć to, co nastąpi dopiero w przyszłości. Wiedza, dotycząca przyszłych przygodnych działań człowieka lub zdarzeń losowych, stanowi jeden z trudniejszy problemów (tzw. antynomia wszechwiedzy), związanych z pojęciem wszechwiedzy Boga.

Wiedza każdego typu (potoczna, naukowa, filozoficzna) wiąże się z czynnością jej zdobywania, czyli z poznaniem. W odróżnieniu od człowieka Bóg jest tym, który posiada zdolność nieskończonego poznania. Między poznaniem, którym dysponuje Bóg, a poznaniem przez człowieka zachodzą podobieństwa i różnice. Podstawowe podobieństwo polega na tym, że umysłowe poznanie zarówno Boga, jak i człowieka, dokonuje się dzięki intelektowi. Jednakże są to intelekty o odmiennych możliwościach poznawczych (Tomasz z Akwinu 1998; 2003).

Poznanie człowieka ma zasadniczo charakter dyskursywny, chociaż jest w nim obecna również intuicja. Dlatego nabywanie wiedzy dokonuje się głównie poprzez analizę, syntezę, klasyfikację, 
przechodzenie od skutków do przyczyny, od rzeczy znanych do nieznanych itp. Jest to poznanie sukcesywne z perspektywą poszerzania i pogłębiania. Natomiast poznanie Boga nie powiększa się. Bóg ma wiedzę, lecz jej nie zdobywa. Sposób Bożego poznania polega na tym, że poznaje wszystko w sobie, czyli całe stworzenie widzi w sobie samym jako w przyczynie (Tomasz z Akwinu 1961-1986; 2006). Z tego powodu w Bożym poznaniu nie występuje następstwo myśli, zwane rozumowaniem. Nie ma w nim również miejsca na przebywanie etapów poznania, gdyż jest to poznanie intuicyjne (oglądowe). Bóg nie dokonuje wnioskowania ani odkrywania prawdy; on wiedzę po prostu posiada (Kowalczyk 2001).

Natomiast człowiek nie poznaje rzeczy w pełni, lecz fragmentarycznie (aspektowo). Bezpośrednio dany jest mu świat materialny, a o świecie duchowym wie o tyle, o ile umożliwia mu to wnioskowanie. Ponadto wiele problemów pozostaje poza zasięgiem jego poznania. Np. nie zna przyszłości, mimo że stara się ją planować lub prognozować (co nie jest jeszcze wiedzą). $Z$ kolei poznanie Boga jest nieskończone zakresowo. W takim samym stopniu dotyczy rzeczywistości materialnej i duchowej, czasu przeszłego i przyszłego. Dlatego poznanie, które Bóg posiada, nazywane jest wszechwiedzą. Bóg wie to, co wiedzieć jest możliwe. Jego wszechwiedza jest prawdziwa, nieomylna i niezmienna. Natomiast poznanie człowieka narażone jest na błędy, pobieżność, zmienność, niepewność (Kowalczyk 2001).

Najtrudniejszy problem, który pozostaje poza zasięgiem zdrowego rozsądku, dotyczy tego, w jaki sposób Bóg zna przyszłość. Głównie chodzi tu o znajomość przygodnych czynów człowieka, które dopiero będą mieć miejsce, choć pojawić się nie muszą. Mowa tu o czynach zależnych tylko i wyłącznie od wolnej woli człowieka ${ }^{16}$.

16 Np. jeszcze nie wiem, czy jutro odwiedzę znajomego, a tym bardziej nie wiem, o której godzinie. Jeśli Bóg już o tym wie, to czy jego wiedza nie determinuje mojego działania? Gdyby tak było, to nie jest ono działaniem wolnym, a nakazanym przez wiedzę Boga (Tomasz z Akwinu 2006; Zagzebski 2012; Gutting 2017; Łukasiewicz 2014). 
Św. Tomasz z Akwinu zajmuje stanowisko, że Bogu znane są przyszłe czyny człowieka. Uzasadnia to przy użyciu dwóch argumentów. Po pierwsze ponieważ Bóg jest wieczny, wszystkie działania, rozgrywające się w czasie, również w przyszłości, postrzega jako teraźniejsze. Dlatego następstwo typu „wcześniej” i „potem” przyjmuje formę „teraz”. Po drugie wolne czyny człowieka Bóg poznaje jako wolne. Wprawdzie dostrzega to, co ma na nie wpływ, czyli wewnętrzną motywacje, prawa przyrody czy oddziaływania społeczne, jednak wiedza tego rodzaju nie pozbawia go wolności działania (Tomasz z Akwinu 1961-1986; 2006; Elders 1992).

\section{WSZECHOBECNOŚĆ}

Doświadczenie charakteru istnienia i sposobu życia człowieka przekonuje, że nie jest on w stanie przebywać w więcej niż w jednym miejscu jednocześnie. Ta sama zasada dotyczy innych bytów, bezpośrednio danych człowiekowi. Zajmować dwa lub więcej miejsc jest niemożliwe. $W$ potocznym rozumieniu terminem wszechobecność zwykło się określać każde miejsce czy też wszystkie miejsca. Być wszechobecnym oznacza znajdować się w każdym miejscu lub nie pozostawiać żadnego wolnego miejsca (Tomasz z Akwinu 1961-1986). Regułą jest, że jednemu ciału przysługuje jedno miejsce. Nawet jeśli materialny przedmiot się przemieszcza, to zawsze pozostaje tylko $\mathrm{w}$ jednym $\mathrm{z}$ miejsc, choćby przebył ich wiele (Tomasz z Akwinu 2005). Na tej podstawie i człowiekowi, i wszystkim innym ciałom nie przypisuje się wszechobecności.

Kwestia atrybutu wszechobecności inaczej przedstawia się w stosunku do Boga. Zdroworozsądkowe próby pojmowania Boga jako wszechobecnego nie są bezpodstawne. Skoro Bóg poznaje działania wszystkich ludzi (wszechwiedza), to musi być jakoś obecny w tych miejscach, w których oni się znajdują. Jednak z drugiej strony kwestia wszechobecności napotyka na pewne trudności. Jedną z nich jest na przykład to, w jaki sposób Bóg zajmuje jakiekolwiek miejsce, 
skoro jest bezcielesny? Zdrowy rozsądek jest przekonany, że tylko ciało może wypełnić jakąś przestrzeń. Oczywistym jest twierdzenie, zgodnie z którym to, co nie ma ciała, nie zajmuje żadnego miejsca.

Wbrew zdrowemu rozsądkowi, na gruncie poznania filozoficznego uzasadnia się, że bezcielesność Boga jest jednym z tych atrybutów, który umożliwia mu bycie wszędzie. Św. Tomasz z Akwinu wyjaśnia, że dwojako można rozumieć stwierdzenie, że coś jest w określonym miejscu. Po pierwsze konkretnie, jak np. to, że Wyższe Seminarium Duchowne znajduje się przy ul. Kościuszki 9 w Ełku. Po drugie ogólnie, gdy nie chodzi o samą rzecz, lecz o cechę lub własność rzeczy, np. rozumność w człowieku lub sferyczność w kuli. Nie należy przy tym zapominać, że samo miejsce to też pewnego rodzaju rzecz.

Jeśli chodzi o Boga, to jest on obecny w każdym miejscu na dwa wyżej wskazane sposoby. Po pierwsze Bóg jest obecny w każdej rzeczy przez to, że daje jej istnienie i działanie (a i samemu miejscu udziela tego samego). Wtedy Bóg znajduje się w rzeczy jak przyczyna w skutku (Moskal 2001). Zatem we wszystkim, co stworzył, jest on obecny, podobnie jak malarz jest obecny w namalowanym przez siebie obrazie. Po drugie Bóg zajmuje miejsce w taki sam sposób, w jaki czynią to różne przedmioty, z tą tylko różnicą, że nie robi tego tak, jak inne ciała. Obecność jednego ciała w określonym miejscu sprawia, że wykluczona zostaje obecność innych ciał. Gdy Bóg zajmuje jakieś miejsce, to nie wyklucza tym samym obecności innych ciał. Zgodnie z tym Bóg dzieli to samo miejsce z rzeczą, której udziela istnienia.

Bóg jest wszechobecny na tej podstawie, że jest we wszystkich rzeczach (łącznie z miejscem) jako ich przyczyna sprawcza, wzorcza i celowa. Każda rzecz stworzona uobecnia Boga - jej sprawcę, wzór i cel. Drugi sposób jego obecności jest taki, jak np. obecność rzeczy poznawanej w podmiocie poznającym lub osoby kochanej w tym, który kocha ${ }^{17}$. Wszechobecność Boga świadczy o tym, że nie ma

17 Kto poznaje (intelekt) lub kocha (wola) Boga, w tym Bóg jest obecny. 
takiego miejsca, w którym Bóg byłby nieobecny. Jego obecność może być ograniczona tylko absolutnym brakiem miejsca, czyli niebytem ${ }^{18}$.

\section{PODSUMOWANIE}

Najbardziej podstawowym typem poznania, jakim dysponuje człowiek, jest poznanie zdroworozsądkowe. Ukształtowane w ramach nurtu realistycznego, umożliwia ono nabywanie fundamentalnych przekonań, dotyczących realnego świata. Zalicza się do nich również sąd o istnieniu Boga, a także przekonania, dotyczące niektórych jego atrybutów. Charakter poznania potocznego przesądza o tym, że wiedza o Bogu i jego własnościach nie posiada dostatecznego ugruntowania i uzasadnienia. Nie znaczy to, że jest bezwartościowa. Jednak z drugiej strony domaga się doprecyzowania na wyższym poziomie poznania w postaci np. filozofii (realistycznej). Tego rodzaju konieczność wynika z różnego rodzaju trudności, których rozwiązanie leży poza zasięgiem poznania przednaukowego.

Problemy, przewyższające zdolności zdrowego rozsądku, pojawiają się także na gruncie problematyki atrybutów Boga. Przy bardziej szczegółowych analizach zrozumienie każdej z zaprezentowanych wyżej własności Boga natrafia na problemy, które okazują się zbyt skomplikowane do rozwiązania przy pomocy jedynie poznania potocznego. Być może dla kogoś, kto poprzestaje tylko na tego typu poznaniu, ich rozstrzygnięcie nie jest istotne $\mathrm{z}$ punktu widzenia praktyki życiowej. Wiedza o tym, że własności typu wszechmoc, wszechwiedza czy wszechobecność nie przysługują ani rzeczom, ani człowiekowi, lecz Bogu jest już pewną podstawą w pojmowaniu natury Boga (przyjmowanej na gruncie filozofii realistycznej i teologii

18 Podobnie do zagadnienia wszechobecności Boga w przestrzeni można podjąć problem wszechobecności Boga w czasie: czy Bóg jest obecny w każdym czasie, również w tym, który przeminął i w tym, który dopiero nastąpi? Ten atrybut Boga zwie się wiecznością (Tomasz z Akwinu 1961-1986). 
katolickiej). Natomiast brak szczegółowej wiedzy na temat tego, że wszechmoc Boga nie oznacza mocy sprawczej do wykonania każdego stanu rzeczy, że wszechwiedza Boga dotyczy również przygodnych decyzji człowieka, że wszechobecność ma miejsce nawet przy braku cielesności - wydaje się usprawiedliwiony na etapie poznania potocznego. Poszukiwanie odpowiedzi na pytania, dotyczące atrybutów Boga, nie wchodzi w zakres kompetencji poznania przednaukowego. Jednak świadomość trudności i zarazem pragnienie wiedzy pobudza i angażuje poznanie innego rodzaju.

Dążenie człowieka do rozwoju nie tylko w wymiarze intelektualnym (poznanie prawdy) konfrontuje zdrowy rozsądek $z$ innymi rodzajami poznania. W każdej ze stref ludzkiej aktywności istnieje możliwość dopełnienia podstawowego typu poznania poznaniem doskonalszym. Trudności, związane z atrybutami Boga, napotykane w poznaniu przednaukowym, wyzwalają poszukiwanie rozwiązań na gruncie filozofii. Jeśli jednak z różnych powodów nie ma ono miejsca, to poznanie zdroworozsądkowe zapewnia człowiekowi minimum rozeznania w tym temacie. Zestawienie dwóch typów poznania, dokonane $\mathrm{w}$ niniejszym opracowaniu, potwierdza, że filozofia realistyczna stanowi dopełnienie poznania potocznego i w tym sensie jest od niego zależna, natomiast relacja odwrotna nie jest tak samo konieczna.

\section{BIBLIOGRAFIA}

Arystoteles. (2009). Metafizyka. Tłum. K. Leśniak. Warszawa: Wydawnictwo Naukowe PWN.

Arystoteles. (2012). Etyka nikomachejska. Tłum. D. Gromska. Warszawa: Wydawnictwo Naukowe PWN.

Augustyn. (1952). Kazanie do katechumenów o wyznaniu wiary. W: Tenże, Pisma katechetyczne. Tłum. W. Budzik, 61-76. Warszawa: Instytut Wydawniczy PAX. Bejze, B. (1968). Filozoficzne rozumienie istoty Boga. W: B. Bejze (red.), O Bogui o cztowieku, t. 1, 105-120. Warszawa: Wydawnictwo ss. Loretanek-Benedyktynek. 
Daszkiewicz, W. (2007). Poznanie zdroworozsq dkowe i jego funkcja w filozofi realistycznej w ије̨сіu Mieczystawa A. Krapca OP. Człowiek w Kulturze, 19, 243-263. Daszkiewicz, W. (2008). Zdrowy rozsqdek. W: A. Maryniarczyk (red.). Powszechna encyklopedia fllozofii, t. 9, 909-912. Lublin: Polskie Towarzystwo Tomasza z Akwinu.

Daszkiewicz, W. (2014). Intuicja intelektualna w metafizyce. Lublin: TN KUL. Elders, L.J. (1992). Filozofia Boga. Filozoficzna teologia św. Tomasza z Akwinu. Tłum. M. Kiliszek, T. Kuczyński. Warszawa: Agencja Wydawnicza Katolików MAG.

Gilson, E. (1968). Realizm tomistyczny. Warszawa: Instytut Wydawniczy PAX.

Gilson, E. (1996). Trudny ateizm. W: Tenże, Bóg i ateizm. Tłum. P. Murzański, 109-181. Kraków: Wydawnictwo Znak.

Gutting, G. (2017). Wiara i fllozofia. Rozmowy wspótczesnych filozofórw o Bogu. Tłum. P. Borkowski. Warszawa: Instytut Wydawniczy PAX.

Herbut, J. (2000). Wiedza zdroworozsqdkowa. Studia Philosophiae Christianae, 36(2), 95-106.

Jaworski, M. (1969). Bóg filozofów a Bóg wierzacych. W: B. Bejze (red.). O Bogu i o cztowieku, t. 2, 97-106. Warszawa: Wydawnictwo ss. Loretanek-Benedyktynek.

Judycki, S. (2010). Bóg i inne osoby. Próba z zakresu teologii filozoficznej. Poznań: W drodze.

Judycki, S. (2009). Wszechmoc i istnienie. Diametros, 21, 30-63.

Kamiński, S. (1989). Typy ludzkiej wiedzy. W: Tenże, Jak flozofować? Studia z metodologii filozofii klasycznej, 13-32. Lublin: TN KUL.

Kamiński, S. (1998). Zasadnicze aspekty poznania Boga, w: Tenże, Światopogląd. Religia. Teologia. Zagadnienia filozoficzne i metodologiczne, 287-292. Lublin: TN KUL.

Kamiński, S. (2017). Epistemologiczno-metodologiczne problemy fllozoficznego poznania Boga. W: S. Janeczek, A. Starościc (red.). Filozofia Boga, cz. 2, 9-44. Lublin: Wydawnictwo KUL.

Koszkało, M., Pepliński, M. (2016). Wszechmoc. W: J. Salamon (red.). Przewodnik po fllozofii religii. Nurt analityczny, 37-59. Kraków: Wydawnictwo WAM.

Kowalczyk, S. (2001). Filozofia Boga. Lublin: Wydawnictwo KUL.

Kowalczyk, S. (2009). Nurty filozofii Boga w Polsce w latach 1880-2008. Lublin: Wydawnictwo KUL.

Krąpiec, M.A. (1981). Poznanie Boga w ujęciu J. Maritaina. Summarium, 10, 127-132.

Krąpiec, M.A. (1991). U podstaw rozumienia kultury. Lublin: RW KUL. 
Krąpiec, M.A. (1993). Zdrowy rozsqdek a krytyka poznania. W: Tenże, Odzyskać swiat realny, 56-73. Lublin: TN KUL.

Krąpiec, M.A. (1995). Realizm ludzkiego poznania. Lublin: RW KUL.

Krąpiec, M.A. (2005). Ja - cztowiek. Lublin: Wydawnictwo KUL.

Krąpiec, M.A. (2008). Elementy filozofii poznania. W: Wprowadzenie do filozofii, (dz. zb.), 335-396. Lublin: Wydawnictwo KUL.

Leszczyński, D. (2011). Zdrowy rozsqdek i sceptycyzm. Roczniki Filozoficzne, 59(1), 5-34.

Eukasiewicz, D. (2014). Opatrzność Boża, wolność, przypadek. Studium zanalitycznej filozofi religii. Poznań: $\mathrm{W}$ drodze.

Łukasiewicz, D. (2016). Atrybuty Boga. W: J. Salamon (red.). Przewodnikpo filozofii religii. Nurt analityczny, 11-17. Kraków: Wydawnictwo WAM.

Maritain, J. (1946-1947). Une nouvelle approche de Dieu. Nova et Vetera, 21-22, 113-129.

Maryniarczyk, A. (2001). Pierwsze zasady wyrazem porzadku racjonalnego. Interpretacja metafizycznych pierwszych zasad. W: Tomasz z Akwinu, Dysputy problemowe O prawdzie. Tłum. A. Białek, 213-225. Lublin: Wydawnictwo KUL. Mazur, P.S. (2004). O nazwach intelektu. Lublin: Wydawnictwo KUL.

Moskal, P. (2000). Spór o racje religii. Lublin: TN KUL.

Moskal, P. (2001). Transcendencja i immanencja Boga w stosunku do świata. W: Z.J. Zdybicka i in. (red.). Wierność rzeczywistości. Księga Pamiatkowa z okazji jubileuszu 50-lecia pracy naukowej na KUL O. prof. Mieczystawa A. Krapca, 145-153. Lublin: Polskie Towarzystwo Tomasza z Akwinu.

Moskal, P. (2008). Religia i prawda. Lublin: Wydawnictwo KUL.

Pepliński, M. (2015). Problematyka wszechmocy Boga - rzeczy nowe i stare. Filo-Sofija, 30(3), 11-44.

Ratzinger, J. (1994). Wprowadzenie w chrześcijaństwo. Tłum. Z. Włodkowa. Kraków: Wydawnictwo Znak.

Ratzinger, J. (2020). Wiara między rozumem a uczuciem. W: Tenże. Prawda i wolność. Rozważania o wspótczesności. Tłum. R. Zajączkowski, 19-58. Kraków: Wydawnictwo WAM.

Reale, G. (1999). Historia filozofii starożytnej, t. 4. Tłum. E.I. Zieliński. Lublin: RW KUL.

Sieńkowski, M. (2014). Wiara a inne typy poznania. Civitas et Lex, 4, 69-81.

Sieńkowski, M. (2020). Wiara a racjonalność. Ełk: Wydawnictwo Diecezjalne Adalbertinum.

Stępień, A.B. (1989). Wstęp do filozofii. Lublin: TN KUL. 
Tarasiewicz, P. (2011). Rozum i wiara jako źródta wiedzy o Bogu wedtug Zofii J. Zdybickiej USJK. Studia Ełckie, 13, 101-111.

Tatarkiewicz, W. (1986). Droga do flozofii. W: Tenże. O fllozofii i sztuce, 17-40. Warszawa: Wydawnictwo Naukowe PWN.

Tkaczyk, M. (2017). Antynomie wszechmocy i wszechwiedzy Boga. W: S. Janeczek, A. Starościc (red.). Filozofia Boga, cz. 2, 395-414. Lublin: Wydawnictwo KUL. Tomasz z Akwinu. (1961-1986). Suma teologiczna, t. 1-34. Tłum. S. Bełch. London: Katolicki Ośrodek Wydawniczy „Veritas”.

Tomasz z Akwinu. (1998). Kwestie dyskutowane o prawdzie, t. 1-2. Tłum. A. Aduszkiewicz, L. Kuczyński, J. Ruszczyński. Kęty: Wydawnictwo ANTYK.

Tomasz z Akwinu. (2003). Summa contra gentiles, t. 1. Tłum. Z. Włodek, W. Zega. Poznań: $\mathrm{W}$ drodze.

Tomasz z Akwinu. (2005). O poznaniu Boga. Tłum. P. Lichacz. Kraków: Wydawnictwo M.

Tomasz z Akwinu (2006). Dysputy problemowe O wiedzy Boga. W: Tenże. Dysputy problemowe „O ideach”, „O wiedzy Boga”. Tłum. A. Białek, 65-205. Lublin: Wydawnictwo KUL.

Tupikowski, J. (2008). Byt i Tajemnica. Zarys filozofii Boga. Warszawa: Wydawnictwo Misjonarzy Klaretynów.

Wojtysiak, J. (2013). Wprowadzenie do teologii naturalnej. Kraków: Fundacja „Dominikańskie Studium Filozofii i Teologii”.

Zagzebski, L. (2012). Wprowadzenie historyczne do filozofii religii. Tłum. A. Szwed. Kraków: Wydawnictwo WAM.

Zdybicka, Z.J. (1977). Cztowiek i religia. Lublin: TN KUL.

\section{COMMON-SENSE AND PHILOSOPHICAL KNOWLEDGE OF GOD'S ATTRIBUTES}

Abstract. The problem considered in this article concerns the relationship between the pre-scientific and philosophical knowledge of God's attributes. The paper argues that although common sense does not experience omnipotence, omniscience and omnipresence directly in the world, it nevertheless attributes them to God. Common sense, however, cannot justify their attribution to God. The problem of justification arising from a pre-scientific cognition is dealt with, among others, by philosophers. On the one hand, this confirms the idea that philosophy corrects and complements pre-scientific cognition. On the other hand, however, it is argued that pre-scientific knowledge is sufficient to recognise and get acquainted with God's attributes.

Keywords: knowledge; common sense; philosophy; attributes of God; omnipotence; omniscience; omnipresence; antinomy 
MARCIN SIEŃKOWSKI

Wyższe Seminarium Duchowne Diecezji Ełckiej

(The Higher Theological Seminary of Ełk Dioceses, Poland)

ORCID: https://orcid.org/0000-0002-0679-5006

sienkowskimarcin@interia.pl

DOI: 10.21697/spch.2021.57.A.04

${ }_{\text {OPEN }} \partial_{\text {access }}$ (C) $\underset{\mathrm{BY}}{\mathrm{N}} \Theta_{\mathrm{ND}}$

Artykuł jest udostępniany na zasadach licencji Creative Commons (CC BY-ND 4.0 Międzynarodowe). Zgłoszono: 16/01/2021. Zrecenzowano: 09/03/2021. Zaakceptowano do publikacji: 11/05/2021. 